\title{
The effects of male age on sperm DNA damage: an evaluation of 2,178 semen samples
}

\author{
Claudia G. Petersen ${ }^{1,2}$, Ana L. Mauri ${ }^{1,2}$, Laura D. Vagnini ${ }^{2}$, Adriana Renzi ${ }^{2}$, Bruna Petersen ${ }^{2}$, Mariana Mattila ${ }^{1}$, \\ Vanessa Comar ${ }^{1}$, Juliana Ricci ${ }^{1}$, Felipe Dieamant ${ }^{1}$, Joao Batista A. Oliveira ${ }^{1,2}$, Ricardo L. R. Baruffi ${ }^{1,2}$, Jose G.
} Franco Jr. ${ }^{1,2}$

${ }^{1}$ Center for Human Reproduction Prof. Franco Jr., Ribeirão Preto, SP, Brazil

${ }^{2}$ Paulista Center for Diagnosis, Research, and Training, Ribeirão Preto, SP, Brazil

Presented at the $32^{\text {nd }}$ ESHRE Annual Meeting in Helsinki, Finland, 2016

\begin{abstract}
Objective: This study aimed to evaluate the effects of male age on sperm DNA damage.

Methods: This cross-sectional study included semen samples collected from 2,178 men seen at an infertility clinic. For DNA integrity analysis, the proportions of spermatozoa showing DNA fragmentation (TUNEL assay), abnormal chromatin packaging/underprotamination (chromomycin $\mathrm{A}_{3}$ ), abnormal mitochondrial membrane potential (MMP/MitoTracker Green), and apoptosis (annexin V) were recorded. For group comparisons, enrolled subjects were divided into three groups based on their ages: $\leq 35$ years; 36-44 years; and $\geq 45$ years. The associations between age and sperm parameters were assessed using Spearman's rank correlation coefficient.

Results: Although aging did not affect sperm apoptosis $(p>.05)$, sperm DNA fragmentation and MMP deteriorated significantly with age $(p<.05)$. Chromatin packaging/protamination improved significantly with age $(p<.05)$.

Conclusion: Sperm DNA fragmentation worsened with age and was apparently associated with mitochondrial damage. The age-related increase in sperm DNA damage suggests that delaying childbearing, not only in women but also in men, might jeopardize a couple's reproductive capacity. The increase seen in chromatin packaging might represent a protective feature for DNA. However, additional studies must be performed to confirm the results concerning chromatin packaging/protamination.
\end{abstract}

Keywords: Male age, DNA damage, sperm, functional parameters

\section{INTRODUCTION}

The hormonal and cellular changes introduced by the aging process affect human fertility. Understanding the effect of age on fertility is important, since couples in today's society frequently postpone parenthood. The female biological clock has been established as having a negative effect on fertility. However, with respect to evaluating men in terms of this concern, the effects of male aging have not been established, although increasing evidence suggests that advanced paternal age affects fertility, independent of maternal age (Andolz et al., 1999; Girsh et al., 2008; Dain et al., 2011; Zhu et al., 2011). The general consensus is that increasing paternal age tends to be associated with a decline in semen quality with respect to basic, structural, and functional sperm parameters. Several studies have established that semen volume and motility decrease in 50-year-old men (Neaves et al., 1984). However, studies analyzing male age have demonstrated declines in structural and functional parameters and established the age of 40 as a cutoff or turning point (Guérin et al., 2005;
Evenson \& Wixon, 2006; Belloc et al., 2008). Additionally, studies have indicated that advanced paternal age increases the risk of miscarriage (Slama et al., 2005; Kleinhaus et al., 2006) and the potential of certain diseases occurring in the offspring, such as genetic abnormalities, pediatric cancer, and several neuropsychiatric disorders (Hemminki \& Kyyrönen, 1999; Wyrobek et al., 2006; O'Roak et al., 2012; Crosnoe \& Kim, 2013; Paul \& Robaire, 2013). Advanced male age has also been correlated with infant mortality (Urhoj et al., 2014). One likely explanation for these outcomes is that older men may have more sperm with damaged DNA.

The exact mechanism for age-dependent patterns of sperm decline is still not fully understood. Several factors such as free radical theory and apoptosis, fertilization capacity, DNA mutation, other diseases, and changes in telomeres have been discussed in the literature. It has been scarcely suggested that oxidative stress and reactive oxygen species (ROS) are important contributors for both damage to the DNA of the nucleus and of the mitochondria and decrease in sperm motility. Increased age causes an accumulation of ROS, promoting increased oxidative stress that induces lipid peroxidation and further ROS generation. An excessive amount of ROS and decreased antioxidant capacity in the course of aging may induce apoptosis or oxidative damage to DNA (Aitken, 1989). The damaged paternal DNA, if not repaired, may through fertilization reach the couple's offspring, causing a variety of diseases (Gunes et al., 2016). Older men are believed to produce more sperm with DNA damage, gene mutations, and aneuploidy (Nijs et al., 2011; Plastira et al., 2007). A systematic review and meta-analysis (Johnson et al., 2015) suggested that greater focus on DNA fragmentation and progressive motility in a clinical setting might produce better patient outcomes during fertility treatments of aging couples.

To better understand sperm quality and function, a variety of methods, such as tests to quantify protamination and DNA packaging, DNA fragmentation, chromosome aneuploidy, and molecular karyotyping, have been applied in the evaluation of infertile males (Patassini et al., 2013; Ferlin \& Foresta, 2014; Tsuribe et al., 2016). However, only a few studies have described semen cytochemical parameters such as apoptotic and DNA mitochondrial damage. The objective of this study was to evaluate the correlations between male age and four sperm biomarkers - DNA fragmentation, chromatin packaging, apoptosis, and mitochondrial damage - in a large population.

\section{MATERIAL AND METHODS}

\section{Study Participants}

This prospective study was based on a cohort of 2178 consecutive men from couples undergoing infertility investigation and treatment from January 2007 to December 2015. The exclusion criteria were azoospermia, any known 
reproductive tract pathology in the last six months, any hormonal therapy in the last six months, chronic medical disorders, congenital genital tract abnormalities or previous treatment that might have affected fertility (cancer treatment). The participants gave written consent to joining the study. The local Institutional Review Board approved the study.

\section{Sample collection}

Semen samples were collected in sterile containers by masturbation after a sexual abstinence period of 2-5 days. A portion of each sêmen sample was used for analysis according to the WHO guidelines (WHO, 2010). The other portion of each semen sample was immediately processed for morphological analysis by motile sperm organelle morphology examination (MSOME). The remainder of the semen samples was immediately processed for sperm DNA fragmentation analysis using the TdT (terminal deoxynucleotidyl transferase)-mediated dUTP nick-end labelling (TUNEL) assay, sperm apoptosis analysis using the annexin $\mathrm{V}$ assay, sperm chromatin packing/protamination using chromomycin $\mathrm{A} 3\left(\mathrm{CMA}_{3}\right)$ staining and sperm mitochondrial membrane potential (MMP) using MitoTracker Green FM.

\section{Cytochemical Evaluation \\ Determination of sperm DNA fragmentation/ TdT-mediated dUTP TUNEL \\ DNA fragmentation in spermatozoa was measured using} the TUNEL assay, performed using an in situ cell death detection kit and tetramethylrhodamine-red labelled dUTP (Roche), as previously described (Vagnini et al., 2007; Oliveira et al., 2014). The final evaluation was performed using a fluorescence microscope (Olympus BX 50), and the proportion of TUNEL-positive spermatozoa was determined. At least 200 sperms per slide were evaluated, using the appropriate filter.

Determination of sperm chromatin packaging/ protamination/chromomycin $\mathrm{A}_{3}\left(\mathrm{CMA}_{3}\right)$ staining

Sperm protamine deficiency (underprotamination)/chromatin packaging was measured using $\mathrm{CMA}_{3}$ (Sigma-Aldrich), as previously described (Franco et al., 2012). The proportion of positive spermatozoa was determined by direct observation in four fields on a fluorescence microscope (Olympus BX 50 ), and the proportion of spermatozoa with abnormal chromatin packaging was determined. At least 200 sperms per slide were evaluated, using the appropriate filter.

\section{Determination of sperm apoptosis/annexin $V$ binding}

Sperm apoptosis was measured using annexin V, a calcium-dependent phospholipid-binding protein with a high affinity for phosphatidylserine that is present in the inner leaflet of the sperm membrane, except in apoptotic sperm, where phosphatidylserine is externalized. The sperm suspensions $\left(1 \times 10^{6}\right.$ cells $\left./ \mathrm{mL}\right)$ were incubated in an appropriate binding buffer with $1 \mu \mathrm{L}$ of annexin $\mathrm{V}$ (green), $1 \mu \mathrm{L}$ of propidium iodide (PI) (red) (Dead Cell Apoptosis Kit with Annexin V Alexa Fluor ${ }^{\circledR} 488$ \& Propidium Iodide, Molecular Probes ${ }^{\mathrm{TM}}$, Eugene, OR) and $1 \mu \mathrm{L}$ of cell-permeable DNA stain Hoechst 33342 (blue) (Molecular Probes) at room temperature for $15 \mathrm{~min}$ in the dark. PI is impermeable to live cells. After incubation, the suspension was centrifuged at $800 \mathrm{~g}$ for $10 \mathrm{~min}$, and the pellet was mounted on poly-I-lysine-coated slides for examination, using a fluorescence microscope (Olympus BX 50). The results demonstrated that subpopulations of sperm could be identified: annexin $\mathrm{V}(-) / \mathrm{PI}(-)$ - live intact sperm; annexin $\mathrm{V}(+) /$ $\mathrm{PI}(-)$ - early apoptotic cells; and annexin $\mathrm{V}(+/-) / \mathrm{PI}(+)$ - necrotic cells. The proportion of early apoptotic cells (defined as the number of positive annexin V/negative PI spermatozoa divided by the total number of spermatozoa $\times 100$ ) was determined. At least 200 sperms per slide were evaluated, using the appropriate filter.

Determination of sperm MMP - MitoTracker Green (MT-G) staining

Sperm MMP, an indicator of sperm mitochondrial functionality, was determined using MG FM (Molecular Probes). The live sperm suspensions were incubated in phosphate-buffered saline (PBS) containing $20 \mathrm{nmol} / \mathrm{L}$ MG for 20 min at $37^{\circ} \mathrm{C}$. To stain sperm DNA, the samples were subsequently incubated in cell-permeable DNA stain Hoechst 33342 (Molecular Probes) for $10 \mathrm{~min}$ at $37^{\circ} \mathrm{C}$. After incubation, the suspension was centrifuged at 800 $g(10 \mathrm{~min})$ and the pellet was mounted on a microscope slide. Green fluorescence in the midpiece indicated active mitochondria. Sperm samples were examined using a fluorescence microscope (Olympus $B X 50$ ) and the proportions of spermatozoa with altered $\mathrm{MMP} /$ mitochondrial damage (i.e., absence of green fluorescence) were determined. At least 200 spermatozoa per slide were evaluated, using the appropriate filter.

\section{Quality control}

To control for intra-observer and inter-observer variability, multiple fractions of semen samples were obtained from randomly selected patients. Each sample was observed at least three times by the same observer (blinded to subject identity). Intra-observer and Inter-observer variations of $\approx 0.5 \%$ to $1 \%$ and $0.5 \%$ to $7 \%$, respectively, were obtained for each parameter analyzed: TUNEL-positive sperm, $\mathrm{CMA}_{3}$-positive sperm, annexin $\mathrm{V}$-positive sperm and MitoTracker Green-positive, sperm semen parameters (according to the WHO guidelines), normality of the spermatozoon (as a whole), and normality of the nuclear structure. The variability observed here was comparable to the variability described in classical sperm quality parameters (Auger et al., 2000).

\section{Sample size}

The sample size was calculated by performing a comparison between two proportions. A sample size of 300 subjects in each group yielded a chance of $80 \%$ of detecting an increase of $10 \%$ with a significance level of 0.05 (two-tailed).

\section{Statistical analysis}

The data were analyzed using software package StatsDirect (Cheshire, UK). Potential confounders - Body Mass Index (BMI), abstinence time, smoking, alcohol, varicocele, and vitamin use - were also assessed. Regression and correlation analyses with continuous variables were performed using Spearman's rank correlation coefficient. For dichotomous variables, the correlations were determined using logistic regression.

The following age ranges were used as cutoff points to divide the subjects into groups: Group 1: $\leq 35$ years; Group 2: 36-44 years; and Group 3: $\geq 45$ years. The Mann-Whitney $U$ test, Student's $t$-test and chi-squared test were used when indicated.

The level of significance was set at $p<0.05$.

\section{RESULTS}

Table 1 shows the characteristics of the male study population.

General characteristics of the male population and age (Table 2)

Table 2 shows the correlation between male general characteristics and age. A significant $(p<0.0001)$ positive correlation was found between age and two characteristics: 
Table 1. General characteristics of the male study population.

\begin{tabular}{|c|c|}
\hline Characteristics & Total \\
\hline Patients $(n)$ & 2178 \\
\hline Age (years) (mean \pm SD) & $37.9 \pm 6.4(\min , 22 ; \max , 76)$ \\
\hline Duration of infertility (years) (mean \pm SD) & $4.1 \pm 2.2$ \\
\hline BMI $($ mean $\pm S D)$ & $28.5 \pm 4.2$ \\
\hline Vitamin supplement use (\%) & $16.7(364 / 2178)$ \\
\hline Varicocele $(\%)$ & $16.0(349 / 2178)$ \\
\hline 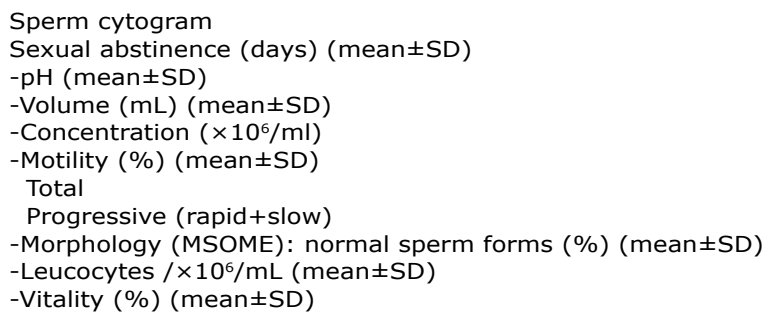 & $\begin{array}{l}3.5 \pm 1.5 \\
8.0 \pm 0.5 \\
2.7 \pm 1.4 \\
74.6 \pm 61.6 \\
63.7 \pm 15.7 \\
56.9 \pm 16.2 \\
0.9 \pm 1.5 \\
0.4 \pm 1.0 \\
65.0 \pm 14.5\end{array}$ \\
\hline
\end{tabular}

Table 2. Correlation between male general population characteristics and age.

\begin{tabular}{|c|c|c|c|c|c|c|c|}
\hline \multirow[b]{2}{*}{ Characteristics } & \multicolumn{4}{|c|}{ Age Groups } & \multicolumn{3}{|c|}{ Regression Analysis } \\
\hline & $\begin{array}{c}\text { Group } 1 \\
(\leq 35 \text { years })\end{array}$ & $\begin{array}{c}\text { Group } 2 \\
(36-44 \text { years })\end{array}$ & $\begin{array}{c}\text { Group } 3 \\
(\geq 45 \text { years })\end{array}$ & $\boldsymbol{p}$ & $\begin{array}{c}\text { Correlation Coefficient } \\
\text { r/OR }\end{array}$ & $95 \% \mathrm{Cl}$ & $\boldsymbol{p}$ \\
\hline Patients (n) & 852 & 1014 & 312 & & & & \\
\hline Age (years) (mean \pm SD) & $32.1 \pm 2.6$ & $39.3 \pm 2.5$ & $49.2 \pm 5.0$ & & & & \\
\hline Father of at least one child (\%) & $23.4(199 / 852)$ & $34.4(348 / 1014)$ & $53.5(167 / 312)$ & $<0.05$ & OR: $1.08 * \bullet$ & 1.06 to 1.09 & $<0.0001$ \\
\hline Smoking (\%) & $11.5(98 / 852)$ & $11.0(112 / 1014)$ & $10.6(33 / 312)$ & 0.22 & OR:0.99•• & 0.97 to 1.01 & 0.45 \\
\hline Regular drinking (\%) & $68.9(587 / 852)$ & $65.7(666 / 1014)$ & $67.3(210 / 312)$ & 0.33 & OR:0.99*• & 0.98 to 1.01 & 0.95 \\
\hline Vitamin supplement use (\%) & $16.5(14 / 852)$ & $16.0(162 / 1014)$ & $19.6(61 / 312)$ & 0.39 & OR: $1.01 *$ & 0.99 to 1.03 & 0.12 \\
\hline Varicocele (\%) & $14.7(125 / 852)$ & $17.6(178 / 1014)$ & $14.7(46 / 312)$ & 0.19 & OR: $1.00 *$ & 0.98 to 1.01 & 0.84 \\
\hline
\end{tabular}

* Spearman's correlation; ** logistic regression; r, Spearman's rank correlation coefficient; OR, odds ratio; CI, Confidence Interval.

being a father with at least one child (OR: 1.08) and duration of infertility $(r: 0.26)$. Other characteristics such as the BMI, smoking, drinking, intake of vitamin supplements, varicocele, and abstinence days, were not correlated with age $(p>0.05)$. The proportion of men who fathered at least one child increased with age. A significantly higher number (\%) of men aged $\geq 45$ years (Group III) had fathered at least one child, compared to the number of men aged 36-40 years (Group II) and men aged $\leq 35$ years (Group I) - $53.5 \%$, $34.4 \%$, and $23.4 \%$, $(p<0.05)$, respectively. Similarly, men aged $\geq 45$ years presented a larger period of infertility when compared to men aged $36-40$ years or $\leq 35$ years $-5.6,4.4$, and $3.1(p<0.05)$, respectively.

\section{Cytochemical sperm parameters}

The overall percentage of DNA fragmentation was $15.4 \pm 8.5 \%$; chromatin packaging was $56.1 \pm 15 \%$; mitochondrial damage was $25.9 \%$; and the proportion of apoptotic cells was $19.2 \%$ (Table 3 ).
Cytochemical sperm parameters and age groups

Table 3 illustrates the cytochemical sperm parameters of 2178 patients divided into three groups based on male age. DNA damage increased with age. Patients aged $\leq 35$ years presented statistically lower levels of DNA damage $(14.7 \%)$ when compared to men aged $36-44$ years $(15.9 \%)$ and men aged $\geq 45$ years $(16.2 \%), p<0.05$. Mitochondrial damage increased with age. Patients aged $\leq 35$ years had a statistically lower proportion of abnormal MMP (24.6\%) when compared to men aged $36-44$ years $(25.6 \%)$ and men aged $\geq 45$ years $(29.0 \%), p \leq 0.05$. Abnormal chromatin packaging decreased as age increased. Patients aged $\leq 35$ years had a statistically higher level of abnormal chromatin packaging DNA damage $(57.7 \%)$ when compared to men aged $36-44$ years $(55.7 \%)$ and men aged $\geq 45$ years $(52.9 \%)$. There were no significant differences among the three groups in relation to age and apoptosis. Patients aged $\leq 35$ years, $36-44$ years, and $\geq 45$ years had $19.1 \%, 19.3 \%$, and $19.3 \%$ of spermatozoa with apoptosis, respectively. 
Table 3. Cytochemical sperm parameters of 2178 patients divided between the three men's age groups.

\begin{tabular}{|c|c|c|c|c|c|}
\hline \multirow[t]{3}{*}{ Cytochemical Sperm Parameters } & \multicolumn{5}{|c|}{ Age Groups } \\
\hline & Total & $\begin{array}{c}\text { Group } 1 \\
\text { ( } \leq 35 \text { years) }\end{array}$ & $\begin{array}{c}\text { Group } 2 \\
\text { (36-44 years) }\end{array}$ & $\begin{array}{c}\text { Group } 3 \\
(\geq 45 \text { years) }\end{array}$ & $\boldsymbol{p}$ \\
\hline & $\mathbf{n}=\mathbf{2 1 7 8}$ & $n=852$ & $n=1014$ & $n=312$ & \\
\hline DNA fragmentation $(\%)($ mean \pm SD) & $15.4 \pm 8.5$ & $14.7 \pm 8.3^{\mathrm{a}, \mathrm{b}}$ & $15.9 \pm 8.7^{a}$ & $16.2 \pm 8.4^{b}$ & $\begin{array}{l}\mathrm{a} 0.002 \\
\mathrm{~b} 0.009\end{array}$ \\
\hline Mitochondrial damage (\% abnormal MMP) $($ mean \pm SD) & $25.9 \pm 16.4$ & $24.6 \pm 16.4^{a}$ & $25.6 \pm 16.0^{\mathrm{b}}$ & $29.0 \pm 17.1^{\mathrm{a}, \mathrm{b}}$ & $\begin{array}{c}\mathrm{a} 0.006 \\
{ }^{\mathrm{b}} 0.04\end{array}$ \\
\hline Chromatin packaging ( $\% \mathrm{CMA}_{3}$ positive) (mean $\pm \mathrm{SD}$ ) & $56.1 \pm 15.2$ & $57.7 \pm 15.0^{\mathrm{a}, \mathrm{b}}$ & $55.7 \pm 15.1^{\mathrm{a}, \mathrm{c}}$ & $52.9 \pm 15.6^{\mathrm{b}, \mathrm{c}}$ & $\begin{array}{c}{ }^{\mathrm{a}} 0.01 \\
{ }^{\mathrm{b}}<0.001 \\
{ }^{\mathrm{c}} 0.01\end{array}$ \\
\hline Apoptosis (\%) (mean \pm SD) & $19.2 \pm 15.2$ & $19.1 \pm 8.0$ & $19.3 \pm 7.9$ & $19.3 \pm 7.8$ & 0.85 \\
\hline
\end{tabular}

Figures 1 through 4 show the correlation between male age and cytochemical sperm parameters. The individual data points and the regression line demonstrated positive correlations between age and the proportion of DNA fragmentation - Spearman's rank correlation coefficient $=0.10 ; p=0.002$ (Figure 1 ) - and age and the proportion of abnormal MMP (Figure 2) - Spearman's rank correlation coefficient $=0.13 ; p<0.0001$. In contrast, a negative correlation was found between age and the proportion of CMA positivity (Figure 3 ) - Spearman's rank correlation coefficient $=-0.13 ; p<0.0001$. No correlation was found between age and proportion of apoptosis (Figure 4) - Spearman's rank correlation coefficient $=0.03 ; p=0.28$.

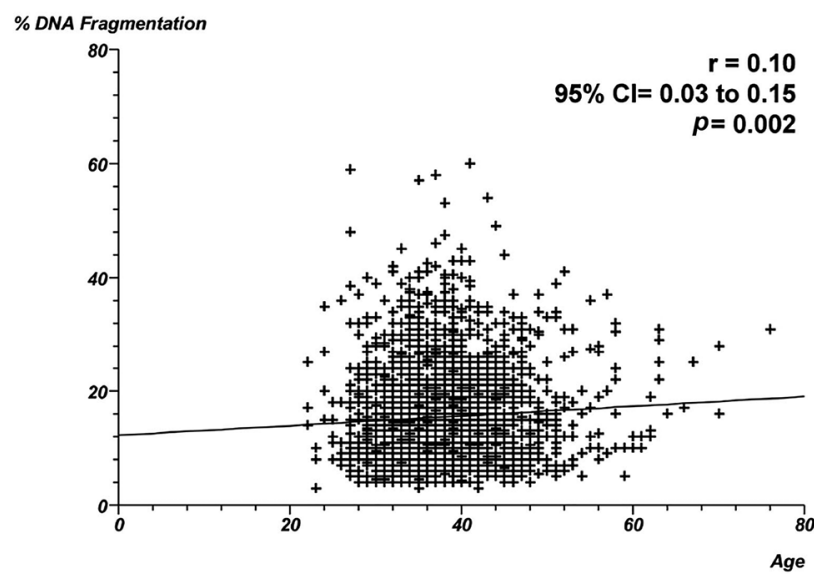

Figure 1. Correlation between male age and proportion of DNA fragmentation. Individual data points and the regression line are shown. Spearman's rank correlation coefficient $=0.10 ; p=0.002$.

\section{DISCUSSION}

This study aimed to use a combination of assays to understand the effect of aging on spermatozoa DNA damage by testing physiologic processes, such as disulfide bond formation, chromatin protamination, and the events that measure functional endpoints, i.e., DNA denaturation and fragmentation. Our results showed that DNA fragmentation increased with age. These findings contrast against reports from other authors (Sun et al., 1997; Winkle et al., 2009; Colin et al, 2010; Brahem et al., 2011; Nijs et al., 2011), in which no relationship was found between DNA fragmentation and age. Factors such as environmental exposure, sickness, differences in sample size, evaluation methods,

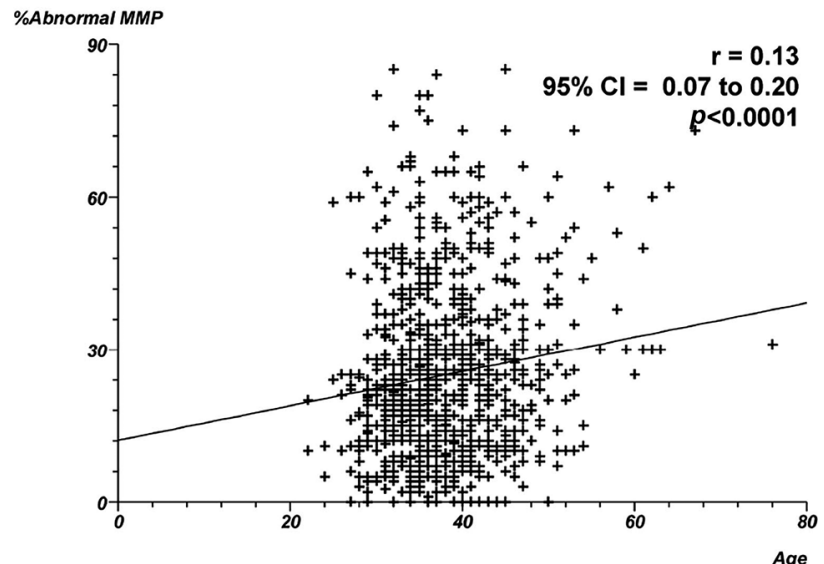

Figure 2. Correlation between male age and proportion of abnormal MMP. Individual data points and the regression line are shown. Spearman's rank correlation coefficient $=0.13 ; p<0.0001$.

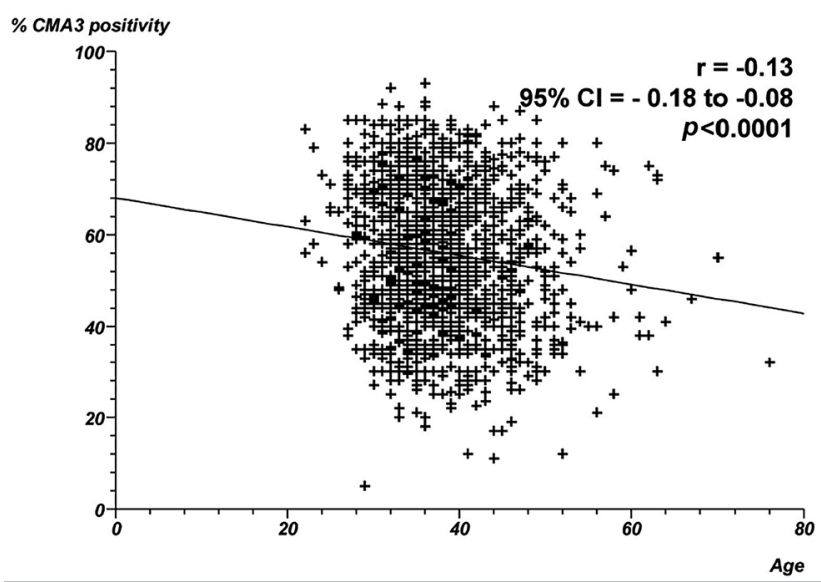

Figure 3. Correlation between male age and proportion of CMA positivity. Individual data points and the regression line are shown. Spearman's rank correlation coefficient $=-0.13 ; p<0.0001$.

and statistical analysis methods might have contributed to the differences between studies. However, our findings were consistent with the majority of studies that show a direct correlation between male age and DNA sperm damage, regardless of the technique used (TUNEL, Comet assay or high DNA stainability/HDS). However, most of these 


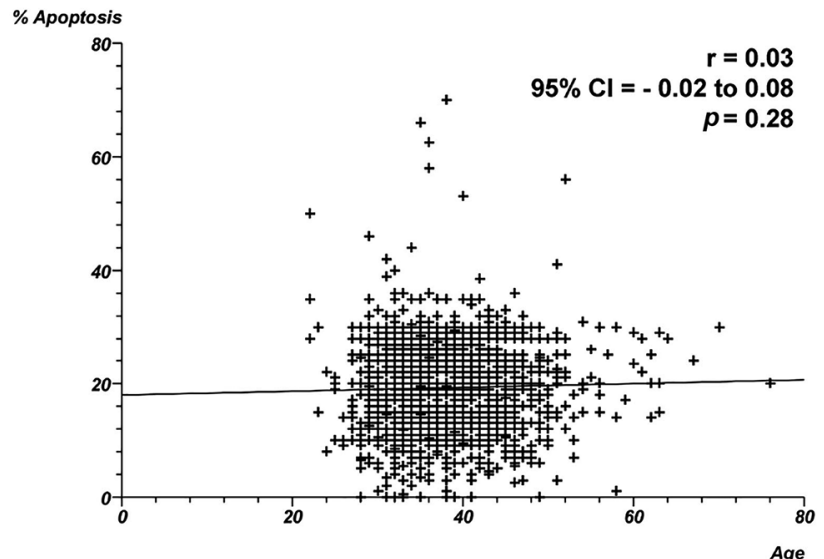

Figure 4. Correlation between male age and proportion of apoptosis. Individual data points and the regression line are shown. Spearman's rank correlation coefficient $=0.03 ; p=0.028$.

studies enrolled a small number $(<300)$ of individuals (Wyrobek et al., 2006; Plastira et al., 2007; Morris et al., 2002; Singh et al., 2003; Schmid et al. 2007; Rybar et al., 2011; Das et al., 2013). With regard to larger population studies, Varshini et al. (2012) investigated 504 subjects and observed that patients over 40 years of age had significantly high levels of DNA damage. Moskovtsev et al. (2006) divided 1125 patients into five age groups and observed that DNA fragmentation significantly increased in individuals over 45 years of age when compared to all other age groups. Two additional studies confirmed the positive correlation between age and DNA fragmentation (Moskovtsev et al., 2007; 2009). Our earlier studies - one with 508 men and another with 1500 men - demonstrated clear increases in sperm DNA damage with age (Vagnini et al., 2007; Oliveira et al., 2014).

Although significant, the correlation between age and DNA fragmentation $(p=0.002)$ might be considered weak (Spearman's $r=0.14$ ), since it was similar to the values reported in the largest studies in the literature $-r=0.29$, $p<0.001$ (Moskovtsev et al., 2007); $r=0.24, p<0.05$ (Moskovtsev et al., 2009). Others have reported stronger correlations between age and DNA fragmentation: Singh et al. (2003), $\mathrm{r}=0.56, p<0.001$; Wyrobek et al. (2006) $r=0.64-0.72, p<0.001$; and Schmid et al. (2007), $r=0.22$, $p<0.05$ in alkaline conditions and $r=0.06, p=0.58$ in neutral conditions. Other authors have described it as a non-significant correlation (Sun et al., 1997). Unfortunately, not all studies have used this type of statistical analysis, which makes the interpretation of correlations a challenge.

Our data demonstrated a positive correlation between mitochondrial membrane potential (MMP) and age $(p<0.001)$. Increased ROS production has been associated with altered mitochondrial membrane permeability with a likely subsequent loss of MMP, culminating with DNA fragmentation and cell death of both somatic cells and spermatozoa (Aitken et al., 2012; Agarwal et al., 2014). The exact mechanisms related to advancing age remain to be unveiled, but the likely role of mitochondria in age-dependent decrease of male fertility might also be substantiated by sperm parameters. In fact, it has been recently demonstrated that sperm mitochondria do produce ROS, thus contributing to the onset of oxidative stress in the male gamete and possibly playing a key role in age-related reproductive pathophysiology (Koppers et al., 2008).

In fact, older men may produce more sperm with DNA fragmentation due to higher exposure to oxidative stress, defective sperm chromatin packaging, and disordered apoptosis (Agarwal \& Said, 2003). The hypothesis is that the presence of DNA damage in mature spermatozoa is correlated with poor chromatin packaging (Ahmadi \& Ng, 1999; Irvine et al., 2000). Double-stranded DNA breaks occur in the male germ during the process of chromatin packaging and are resolved during the spermatid stage of spermatogenesis (Sakkas et al., 1999). Abnormal chromatin packaging has been related to unresolved DNA breaks in immature human spermatozoa (Aitken et al., 2003; Aitken \& De Iuliis, 2007). However, more evidence is required to support this idea.

Sperm packaging is of major importance. The tertiary structure of DNA carries epigenetic messages to the embryo, affects post-fertilization genome reprogramming, and impacts early embryonic development (Carrell, 2008; Rousseaux et al., 2008). However, DNA structure, i.e., condensation of DNA, is far less studied than age. Aniline or toluidine blue (Auger et al., 1990; Dadoune et al., 1988; Hammadeh et al., 2001), which selectively stains lysine-rich histone proteins, and chromomycin $A_{3}$ (CMA3), a guanine-cytosine-specific fluorochrome that competes with protamines for access to DNA (Sakkas et al., 1996), have been used to detect anomalies in protamine packaging. Unexpectedly, $\mathrm{CMA}_{3}$ staining revealed a significantly negative correlation between age and DNA packaging damage in our study. Although difficult to account for, one hypothesis regarding this phenomenon proposes that with age, there is an unbalanced redox system with higher caspase activation. This unbalance in free radicals might affect the disulfide bonds, making the fixation of protamines and chromomycin $A_{3}$ difficult as they compete for the same receptors. Additionally, the pitfalls of the chromomycin $A_{3}$ method cannot be ruled out. Belloc et al. (2009), using aniline blue, also demonstrated a negative correlation between age and chromatin packaging. DNA staining with this method showed a tendency to decrease chromatin damage with age (but the difference was not significant). In contrast, Nijs et al. (2011) showed a weak and significant positive correlation for chromatin packaging: a significantly higher proportion of spermatozoa had poor chromatin packaging and immature chromatin (measure by sperm chromatin structure assay/SCSA) in older individuals than the overall patient population $(n=278)$ $(p=0.035)$. This significant correlation, however, was lost when the patient population was split into three age groups $(p>0.05)$.

The presence of apoptosis in ejaculated human sperm has received considerable attention, since defects in apoptosis have been proposed as an explanation for the generation of sperm DNA fragmentation (Agarwal et al., 2014; Sakkas \& Alvarez, 2010). Ejaculated spermatozoa, particularly from infertile men, have been shown to display morphological and biochemical features that are typical of an apoptotic phenotype in somatic cells (Oehninger et al., 2003; Grunewald et al., 2009). The deregulation of apoptosis is known to play a role in a number of disease processes, and it has been postulated that exacerbated or aberrant apoptosis might determine sperm dysfunction. Alternatively, in older men, the apoptotic functions of spermatogenesis might be defective, resulting in the production of more spermatozoa with fragmented DNA. However, in this study, we were unable to find correlations between age and apoptotic sperm cells. The proportion of spermatozoa detected by sperm phosphatidylserine (PS) translocation and the early apoptotic marker (annexin V) was similar between the three groups. In contrast, Collins et al. (2008) showed that advanced age per se was associated with a significantly increased expression of the early apoptotic biomarker in the ejaculate spermatozoa of healthy and proven fertile men. 
In conclusion, sperm DNA damage seems to be influenced by the aging process. Although the influence of aging on sperm apoptosis was not observed, sperm DNA fragmentation increased with age and was apparently associated with mitochondrial damage. The age-related increase in sperm DNA damage suggests that postponing parenthood, not only in women but also in men, might jeopardize reproductive capacity. The increase in chromatin packaging with age is difficult to explain. The increase in chromatin packaging might represent a protective feature for DNA; however, a pitfall of the chromomycin $\mathrm{A}_{3}$ method cannot be ruled out. Additional studies must be performed to confirm the results concerning chromatin packaging (chromatin protamination) in sperm.

\section{CONFLICTS OF INTEREST}

The authors have no conflicts of interest to report.

\section{Corresponding Author:}

Jose G. Franco Jr

Center for Human Reproduction Prof Franco Jr

Ribeirão Preto - São Paulo - Brazil

E-mail: crh@crh.com.br

\section{REFERENCES}

Agarwal A, Said TM. Role of sperm chromatin abnormalities and DNA damage in male infertility. Hum Reprod Update. 2003;9:331-45. PMID: 12926527 DOI: 10.1093/humupd/dmg027

Agarwal A, Virk G, Ong C, du Plessis SS. Effect of oxidative stress on male reproduction. World J Mens Health. 2014;32:1-17. PMID: 24872947 DOI: 10.5534/ wjmh.2014.32.1.1

Ahmadi A, Ng SC. Developmental capacity of damaged spermatozoa. Hum Reprod. 1999;14:2279-85. PMID: 10469696 DOI: 10.1093/humrep/14.9.2279

Aitken RJ. The role of free oxygen radicals and sperm function. Int J Androl. 1989;12:95-7. PMID: 2722275 DOI: 10.1111/j.1365-2605.1989.tb01290.x

Aitken RJ, Baker MA, Sawyer D. Oxidative stress in the male germ line and its role in the aetiology of male infertility and genetic disease. Reprod Biomed Online. 2003;7:65-70. PMID: 12930576 DOI: 10.1016/S1472-6483(10)61730-0

Aitken RJ, De Iuliis GN. Value of DNA integrity assays for fertility evaluation. Soc Reprod Fertil Suppl. 2007;65:8192. PMID: 17644956

Aitken RJ, Jones KT, Robertson SA. Reactive oxygen species and sperm function-- in sickness and in health. J Androl. 2012;33:1096-106. PMID: 22879525 DOI: 10.2164/jandrol.112.016535

Andolz P, Bielsa MA, Vila J. Evolution of semen quality in North-eastern Spain: a study in 22,759 infertile men over a 36 year period. Hum Reprod. 1999;14:731-5. PMID: 10221705 DOI: $10.1093 /$ humrep/14.3.731
Auger J, Mesbah M, Huber C, Dadoune JP. Aniline blue staining as a marker of sperm chromatin defects associated with different semen characteristics discriminates between proven fertile and suspected infertile men. Int J Androl. 1990;13:452-62. PMID: 1710607 DOI: 10.1111/j.1365-2605.1990.tb01052.x

Auger J, Eustache F, Ducot B, Blandin T, Daudin M, Diaz I, Matribi SE, Gony B, Keskes L, Kolbezen M, Lamarte A, Lornage J, Nomal N, Pitaval G, Simon O, Virant-Klun I, Spira $A$, Jouannet $P$. Intra- and inter-individual variability in human sperm concentration, motility and vitality assessment during a workshop involving ten laboratories. Hum Reprod. 2000;15:2360-8. PMID: 11056133 DOI: $10.1093 /$ humrep/15.11.2360

Belloc S, Cohen-Bacrie P, Benkhalifa M, Cohen-Bacrie M, De Mouzon J, Hazout A, Ménézo Y. Effect of maternal and paternal age on pregnancy and miscarriage rates after intrauterine insemination. Reprod Biomed Online. 2008;17:392-7. PMID: 18765010 DOI: $10.1016 / S 1472-6483(10) 60223-4$

Belloc S, Benkhalifa M, Junca AM, Dumont M, Bacrie PC, Ménézo Y. Paternal age and sperm DNA decay: discrepancy between chromomycin and aniline blue staining. Reprod Biomed Online. 2009;19:264-9. PMID: 19712565 DOI: 10.1016/S1472-6483(10)60083-1

Brahem S, Mehdi M, Elghezal $H$, Saad A. The effects of male aging on semen quality, sperm DNA fragmentation and chromosomal abnormalities in an infertile population. J Assist Reprod Genet. 2011;28:425-32. PMID: 21287403 DOI: $10.1007 / \mathrm{s} 10815-011-9537-5$

Carrell DT. Contributions of spermatozoa to embryogenesis: assays to evaluate their genetic and epigenetic fitness. Reprod Biomed Online. 2008;16:474-84. PMID: 18413055 DOI: $10.1016 / S 1472-6483(10) 60454-3$

Colin A, Barroso G, Gómez-López N, Duran EH, Oehninger $\mathrm{S}$. The effect of age on the expression of apoptosis biomarkers in human spermatozoa. Fertil Steril. 2010;94:2609-14. PMID: 20542266 DOI: 10.1016/j.fertnstert.2010.04.043

Collins JA, Barnhart KT, Schlegel PN. Do sperm DNA integrity tests predict pregnancy with in vitro fertilization? Fertil Steril. 2008;89:823-31. PMID: 17644094 DOI: $10.1016 /$ j.fertnstert.2007.04.055

Crosnoe LE, Kim ED. Impact of age on male fertility. Curr Opin Obstet Gynecol. 2013;25:181-5. PMID: 23493186 DOI: $10.1097 /$ GCO.0b013e32836024cb

Dadoune JP, Mayaux MJ, Guihard-Moscato ML. Correlation between defects in chromatin condensation of human spermatozoa stained by aniline blue and semen characteristics. Andrologia. 1988;20:211-7. PMID: 3177899 DOI: 10.1111/j.1439-0272.1988.tb01058.x

Dain L, Auslander R, Dirnfeld M. The effect of paternal age on assisted reproduction outcome. Fertil Steril. 2011;95:18. PMID: 20932518 DOI: 10.1016/j.fertnstert.2010.08.029 
Das M, Al-Hathal N, San-Gabriel M, Phillips S, Kadoch IJ, Bissonnette $F$, Holzer $H$, Zini A. High prevalence of isolated sperm DNA damage in infertile men with advanced paternal age. J Assist Reprod Genet. 2013;30:843-8. PMID: 23722935 DOI: $10.1007 / \mathrm{s} 10815-013-0015-0$

Evenson DP, Wixon R. Clinical aspects of sperm DNA fragmentation detection and male infertility. Theriogenology. 2006;65:979-91. PMID: 16242181 DOI: $10.1016 / j . t h e r-$ iogenology.2005.09.011

Ferlin A, Foresta C. New genetic markers for male infertility. Curr Opin Obstet Gynecol. 2014;26:193-8. PMID: 24743183 DOI: $10.1097 / G C 0.0000000000000061$

Franco JG Jr, Mauri AL, Petersen CG, Massaro FC, Silva LF, Felipe V, Cavagna M, Pontes A, Baruffi RL, Oliveira JB, Vagnini LD. Large nuclear vacuoles are indicative of abnormal chromatin packaging in human spermatozoa. Int J Androl. 2012;35:46-51. PMID: 21535011 DOI: 10.1111/j.1365-2605.2011.01154.x

Girsh E, Katz N, Genkin L, Girtler O, Bocker J, Bezdin S, Barr I. Male age influences oocyte-donor program results. J Assist Reprod Genet. 2008;25:137-43. PMID: 18392674 DOI: $10.1007 / \mathrm{s} 10815-008-9215-4$

Grunewald S, Sharma R, Paasch U, Glander HJ, Agarwal A. Impact of caspase activation in human spermatozoa. Microsc Res Tech. 2009;72:878-88. PMID: 19455684 DOI: 10.1002/jemt. 20732

Guérin $P$, Matillon $C$, Bleau G, Lévy R, Ménézo Y. Impact of sperm DNA fragmentation on ART outcome. Gynecol Obstet Fertil. 2005;33:665-8. PMID: 16137906 DOI: 10.1016/j.gyobfe.2005.07.015

Gunes S, Hekim GN, Arslan MA, Asci R. Effects of aging on the male reproductive system. J Assist Reprod Genet. 2016;33:441-54. PMID: 26867640 DOI: $10.1007 /$ s10815-016-0663-y

Hammadeh ME, Zeginiadov T, Rosenbaum P, Georg T, Schmidt W, Strehler E. Predictive value of sperm chromatin condensation (aniline blue staining) in the assessment of male fertility. Arch Androl. 2001;46:99-104. PMID: 11297072 DOI: $10.1080 / 01485010117363$

Hemminki K, Kyyrönen P. Parental age and risk of sporadic and familial cancer in offspring: implications for germ cell. Epidemiology. 1999;10:747-51. PMID: 10535790 DOI: 10.1097/00001648-199911000-00016

Irvine DS, Twigg JP, Gordon EL, Fulton N, Milne PA, Aitken RJ. DNA integrity in human spermatozoa: relationships with semen quality. J Androl. 2000;21:33-44. PMID: 10670517 DOI: $10.1002 / j .1939-4640.2000 . t b 03273 . x$

Johnson SL, Dunleavy J, Gemmell NJ, Nakagawa S. Consistent age-dependent declines in human semen quality: a systematic review and meta-analysis. Ageing Res Rev. 2015;19:22-33. PMID: 25462195 DOI: 10.1016/j.arr.2014.10.007
Kleinhaus K, Perrin M, Friedlander Y, Paltiel O, Malaspina D, Harlap S. Paternal age and spontaneous abortion. Obstet Gynecol. 2006;108:369-77. PMID: 16880308 DOI: 10.1097/01.AOG.0000224606.26514.3a

Koppers AJ, De Iuliis, GN, Finnie JM, McLaughlin EA, Aitken RJ. Significance of mitochondrial reactive oxygen species in the generation of oxidative stress in spermatozoa. J Clin Endocrinol Metab. 2008;93:3199-207. PMID: 18492763 DOI: $10.1210 /$ jc. $2007-2616$

Moskovtsev SI, Willis J, Mullen JB. Age-related decline in sperm deoxyribonucleic acid integrity in patients evaluated for male infertility. Fertil Steril. 2006;85:496-9. PMID: 16595239 DOI: $10.1016 /$ j.fertnstert.2005.05.075

Moskovtsev SI, Willis J, White J, Mullen JB. Leukocytospermia: relationship to sperm deoxyribonucleic acid integrity in patients evaluated for male factor infertility. Fertil Steril. 2007;88:737-40. PMID: 17336968 DOI: $10.1016 /$ j.fertnstert.2006.11.132

Moskovtsev SI, Willis J, White J, Mullen JB. Sperm DNA damage: correlation to severity of semen abnormalities. Urology. 2009;74:789-93. PMID: 19643462 DOI: 10.1016/j.urology.2009.05.043

Morris ID, Ilott S, Dixon L, Brison DR. The spectrum of DNA damage in human sperm assessed by single cell gel electrophoresis (Comet assay) and its relationship to fertilization and embryo development. Hum Reprod. 2002;17:990-8. PMID: 11925396 DOI: $10.1093 /$ humrep/17.4.990

Neaves WB, Johnson L, Porter JC, Parker CR Jr, Petty CS. Leydig cell numbers, daily sperm production, and serum gonadotropin levels in aging men. J Clin Endocrinol Metab. 1984;59:756-63. PMID: 6434579 DOI: 10.1210/jcem-59-4-756

Nijs $M$, De Jonge C, Cox A, Janssen M, Bosmans E, Ombelet W. Correlation between male age, WHO sperm parameters, DNA fragmentation, chromatin packaging and outcome in assisted reproduction technology. Andrologia. 2011;43:174-9. PMID: 21561463 DOI: 10.1111/j.1439-0272.2010.01040.x

Oehninger S, Morshedi M, Weng SL, Taylor S, Duran H, Beebe $\mathrm{S}$. Presence and significance of somatic cell apoptosis markers in human ejaculated spermatozoa. Reprod Biomed Online. 2003;7:469-76. PMID: 14656410 DOI: $10.1016 / \mathrm{S} 1472-6483(10) 61892-5$

Oliveira JBA, Petersen CG, Mauri AL, Vagnini LD, Baruffi RLR, Franco JG Jr. The effects of age on sperm quality: an evaluation of 1,500 semen samples. JBRA Assist Reprod. 2014;18:34-41. DOI: 10.5935/1518-0557.20140002

O'Roak BJ, Vives L, Girirajan S, Karakoc E, Krumm N, Coe $B P$, Levy R, Ko A, Lee C, Smith JD, Turner EH, Stanaway IB, Vernot B, Malig M, Baker C, Reilly B, Akey JM, Borenstein $E$, Rieder MJ, Nickerson DA, Bernier R, Shendure J, Eichler EE. Sporadic autism exomes reveal a highly interconnected protein network of de novo mutations. Nature. 2012;485:246-50. PMID: 22495309 DOI: $10.1038 /$ nature 10989 
Patassini C, Garolla A, Bottacin A, Menegazzo M, Speltra E, Foresta C, Ferlin A. Molecular karyotyping of human single sperm by array- comparative genomic hybridization. PLoS One. 2013;8:e60922. PMID: 23565289 DOI: $10.1371 /$ journal.pone.0060922

Paul C, Robaire B. Ageing of the male germ line. Nat Rev Urol. 2013;10:227-34. PMID: 23443014 DOI: $10.1038 /$ nrurol.2013.18

Plastira K, Msaouel P, Angelopoulou R, Zanioti K, Plastiras $A$, Pothos A, Bolaris S, Paparisteidis N, Mantas D. The effects of age on DNA fragmentation, chromatin packaging and conventional semen parameters in spermatozoa of oligoasthenoteratozoospermic patients. J Assist Reprod Genet. 2007;24:437-43. PMID: 17768675 DOI: $10.1007 / \mathrm{s} 10815-007-9162-5$

Rousseaux S, Reynoird N, Escoffier E, Thevenon J, Caron $\mathrm{C}$, Khochbin S. Epigenetic reprogramming of the male genome during gametogenesis and in the zygote. Reprod Biomed Online. 2008;16:492-503. PMID: 18413057 DOI: $10.1016 / \mathrm{S} 1472-6483(10) 60456-7$

Rybar R, Kopecka V, Prinosilova P, Markova P, Rubes J. Male obesity and age in relationship to semen parameters and sperm chromatin integrity. Andrologia. 2011;43:286-91. PMID: 21486403 DOI: 10.1111/j.1439-0272.2010.01057.x

Sakkas D, Urner F, Bianchi PG, Bizzaro D, Wagner I, Jaquenoud N, Manicardi G, Campana A. Sperm chromatin anomalies can influence decondensation after intracytoplasmic sperm injection. Hum Reprod. 1996;11:837-43. PMID: 8671337 DOI: 10.1093/oxfordjournals.humrep.a019263

Sakkas D, Mariethoz E, St. John JC. Abnormal sperm parameters in humans are indicative of an abortive apoptotic mechanism linked to the Fas-mediated pathway. Exp Cell Res. 1999;251:350-5. PMID: 10471320 DOI: 10.1006/excr. 1999.4586

Sakkas D, Alvarez JG. Sperm DNA fragmentation: mechanisms of origin, impact on reproductive outcome, and analysis. Fertil Steril. 2010;93:1027-36. PMID: 20080235 DOI: $10.1016 /$ j.fertnstert.2009.10.046

Schmid TE, Eskenazi B, Baumgartner A, Marchetti F, Young $S$, Weldon $R$, Anderson D, Wyrobek AJ. The effects of male age on sperm DNA damage in healthy non-smokers. Hum Reprod. 2007;22:180-7. PMID: 17053003 DOI: 10.1093/humrep/del338

Singh NP, Muller $\mathrm{CH}$, Berger RE. Effects of age on DNA double-strand breaks and apoptosis in human sperm. Fertil Steril. 2003;80:1420-30. PMID: 14667878 DOI: $10.1016 /$ j.fertnstert.2003.04.002
Slama R, Bouyer J, Windham G, Fenster L, Werwatz A, Swan $\mathrm{SH}$. Influence of paternal age on the risk of spontaneous abortion. Am J Epidemiol. 2005;161:816-23. PMID: 15840613 DOI: $10.1093 /$ aje/kwi097

Sun JG, Jurisicova A, Casper RF. Detection of deoxyribonucleic acid fragmentation in human sperm: correlation with fertilization in vitro. Biol Reprod. 1997;56:602-7. PMID: 9047003 DOI: $10.1095 /$ biolreprod56.3.602

Tsuribe PM, Lima Neto JF, Golim Mde A, Dell'Aqua Cde $\mathrm{P}$, Issa JP, Gobbo CA. Assessment of sperm DNA in patients submitted the assisted reproduction technology procedures. JBRA Assist Reprod. 2016;20:17-22. PMID: 27203301 DOI: 10.5935/1518-0557.20160005

Urhoj SK, Jespersen LN, Nissen M, Mortensen LH, Nybo Andersen AM. Advanced paternal age and mortality of offspring under 5 years of age: A register-based cohort study. Hum Reprod. 2014;29:343-50. PMID: 24316515 DOI: $10.1093 /$ humrep/det399

Vagnini L, Baruffi RL, Mauri AL, Petersen CG, Massaro FC, Pontes A, Oliveira JB, Franco JG Jr. The effects of male age on sperm DNA damage in an infertile population. Reprod Biomed Online. 2007;15:514-9. PMID: 18028741 DOI: $10.1016 / \mathrm{S} 1472-6483(10) 60382-3$

Varshini J, Srinag BS, Kalthur G, Krishnamurthy H, Kumar $P$, Rao SB, Adiga SK. Poor sperm quality and advancing age are associated with increased sperm DNA damage in infertile men. Andrologia. 2012;44:642-9. PMID: 22040161 DOI: $10.1111 / \mathrm{j} .1439-0272.2011 .01243 . x$

WHO World Health Organization. WHO laboratory manual for the Examination and processing of human semen. 5th ed. Geneva: WHO; 2010.

Winkle T, Rosenbusch B, Gagsteiger F, Paiss T, Zoller N. The correlation between male age, sperm quality and sperm DNA fragmentation in 320 men attending a fertility center. J Assist Reprod Genet. 2009;26:41-6. PMID: 19030983 DOI: $10.1007 / \mathrm{s} 10815-008-9277-3$

Wyrobek AJ, Eskenazi B, Young S, Arnheim N, Tiemann-Boege I, Jabs EW, Glaser RL, Pearson FS, Evenson D. Advancing age has differential effects on DNA damage, chromatin integrity, gene mutations, and aneuploidies in sperm. Proc Natl Acad Sci U S A. 2006;103:9601-6. PMID: 16766665 DOI: $10.1073 /$ pnas. 0506468103

Zhu QX, Meads C, Lu ML, Wu JQ, Zhou WJ, Gao ES. Turning point of age for semen quality: a population-based study in Chinese men. Fertil Steril. 2011;96:572-6. PMID: 21782163 DOI: 10.1016/j.fertnstert.2011.06.058 